\title{
Assessment of climate change mitigation potential of the Macedonian transport sector
}

\author{
Aleksandar Dedinec ${ }^{\mathrm{a}, *}$, Natasa Markovska ${ }^{\mathrm{a}}$, Verica Taseska ${ }^{\mathrm{a}}$, Neven Duic ${ }^{\mathrm{b}}$, \\ Gligor Kanevce ${ }^{\text {a }}$ \\ ${ }^{a}$ Research Center for Energy, Informatics and Materials, Macedonian Academy of Sciences and Arts (ICEIM-MANU), Krste Misirkov 2, 1000 Skopje, \\ Macedonia \\ ${ }^{\mathrm{b}}$ Department of Energy, Power Engineering and Environment, University of Zagreb, Faculty of Mechanical Engineering and Naval Architecture, \\ Ivana Lučića 5, 10002 Zagreb, Croatia
}

\section{A R T I C L E I N F O}

\section{Article history:}

Received 7 September 2012

Received in revised form

11 April 2013

Accepted 8 May 2013

Available online 13 June 2013

\section{Keywords:}

Climate change mitigation

Transport

Marginal abatement cost curve

\begin{abstract}
A B S T R A C T
As forecasted by the International Energy Agency Energy Technology Perspectives baseline scenario, the largest increment in LDV (light-duty vehicles) stock, travel demand and transport sector energy consumption will take place in the developing world. In the developing countries where the import of used vehicles is allowed, a considerable portion of the LDV stock increment will be realized with used vehicles.

In this paper, the analytical framework for assessment of climate change mitigation potential of transport sector in developing countries is adapted in order to incorporate the expected vehicle fleet increase with used vehicles. The evaluation of appropriate mitigation strategies is performed using the GHG Costing Model (GACMO), which compares each mitigation option with the BAU (business-as-usual) option and determines its environmental effectiveness $\left(\mathrm{t} \mathrm{CO}_{2}\right.$ reduced) and economic effectiveness (US\$/ $\mathrm{t} \mathrm{CO}_{2}$ reduced).

The adapted analytical framework is applied on the case of transport sector of Macedonia, evaluating appropriate options inline with five mitigation strategies: improvement of vehicle fleet, introduction of low carbon fuels, improvement of travel behaviour, advancement of vehicle equipment and improvement of driver behaviour. The resulting marginal cost curve for the year 2020 indicates a total achievable reduction of $22 \%$ with respect to BAU GHG transport sector emissions, with bulk of it at relatively high specific costs of around $90 \mathrm{US} \$ / \mathrm{t} \mathrm{CO}_{2}$.
\end{abstract}

(c) 2013 Elsevier Ltd. All rights reserved.

\section{Introduction}

In the last two decades climate change has been among the main problems faced daily by humanity. According to the projections from the latest report of the IPCC (Intergovernmental Panel on Climate Change) [1], the global surface temperature will probably rise a further $1.1-6.4{ }^{\circ} \mathrm{C}$ during the twenty-first century. In response, many countries have employed scientific approaches in developing their policies and strategies to reduce GHG (greenhouse gas) emissions (e.g., [2-5]). In many cases the GHG emissions reduction analyses have targeted specific sectors (e.g., [6-8]), including transport sector (e.g., [9]).

Specifically for the transport sector, reducing GHG emissions while meeting the transport sector energy needs, will require

\footnotetext{
* Corresponding author.

E-mail addresses: dedinec@manu.edu.mk (A. Dedinec), natasa@manu.edu.mk (N. Markovska), verica@manu.edu.mk (V. Taseska), neven.duic@fsb.hr (N. Duic), kanevce@sonet.com.mk (G. Kanevce).
}

focusing on a combination of low carbon alternative fuels, advanced vehicle technologies, and behavioural change from consumers - a robust approach for meeting long-term targets while minimizing environmental and economic costs. For example, in the U.S., it is estimated that achieving GHG emission reductions of 30\% below 1990 levels in the year 2050 will end oil imports [10]. An analysis of the Australian road transport GHG emissions [11] has shown that very substantial reductions in fuel carbon intensity are vital to achieve emissions in 2020 being $20 \%$ below 2000 levels and emissions in 2050 being $80 \%$ below 2000 levels. Although the full replacement of fossil fuels by biofuels is not deemed to be achievable, modern biofuels have a crucial role to fulfil in helping the long-term limit to growth of GHG emissions and to lead the transition of the current petroleum-based society towards a more sustainable one [12]. Limited by the regional availability of low-cost biomass, biofuels can be important for meeting mild climate policy targets [13]. The results of a recent empirical investigation [14] highlighted the important role played by biofuels in reducing volatility and systematic risk in a fuel mix 
due to their correlation structure with other fuel technologies. Moreover, in this study, it was shown that $\mathrm{CO}_{2}$ emission reductions associated with such an efficient diversification can diminish to almost $58 \%$ from a $100 \%$ fossil fuels scenario. Developments in non-food based or cellulosic (or second generation) biofuels may offer better hope, yet they still compete with food supply through land use and are currently constrained by a number of technical and economic barriers [15].

In the context of developing countries, the gasoline substitution with bioethanol combined with the introduction of hybrid, flexfuel and fuel cell vehicles was analyzed for Metropolitan Area of Mexico City between 2000 and 2030 [16]. The evolution of the Chinese passenger vehicle fleet between 2010 and 2050 and the effects of downsizing and the penetration of hybrid electric vehicles, plug-in hybrid electric vehicles and battery electric vehicle to reduce energy consumption and GHG emissions, were studied in Ref. [17]. Furthermore, in Ref. [18], the impact of increasing the content of aluminium on the Chinese automobile fleet was examined, but only internal combustion engine vehicles were considered. In order to illustrate future challenges in developing countries due to the increment of LDV (light-duty vehicles) stock, the passenger car fleet evolution in Colombia from 2010 to 2050 was studied in Ref. [19], taking internal combustion engine vehicles, battery electric vehicle and fuel cell hybrid electric vehicles as vehicle alternatives. Common to all these studies is their focus on the introduction of advanced vehicles in the LDV fleet and lightweight materials use, not taking into account the increment of the vehicle stock with used vehicles, which, for some of the developing countries is a realistic option due to the governmental policy to allow import of used vehicles.

The main goal of this paper is to adapt the analytical framework for assessment of climate change mitigation potential of transport sector in developing countries, where the fleet is relatively old and expected to increase significantly in the near future with used vehicles. For that purpose the bottom-up GHG costing model (GACMO) is employed, evaluating the appropriate mitigation options in terms of their environmental effectiveness (volume of GHG emissions reduction) and economic effectiveness (specific cost of reduction). The increment of the vehicle fleet with used cars is taken into account by introducing specific assumptions for the mitigation strategy related to vehicle fleet improvement. The model is used to study the mitigation potential of the transport sector in Macedonia. The total achievable emission reduction in 2020 is estimated to $22 \%$ of the BAU transport sector emissions and the bulk of it can be realized at relatively high specific costs of around $90 \mathrm{US} \$ / \mathrm{tCO}_{2}$. Furthermore, the results of the participatory prioritization of the mitigation strategies are discussed along with policy recommendations which should contribute towards formulation of wise and well-informed transport sector policies, reflecting also the commitment for climate change mitigation.

\section{Methodology}

The basis for a mitigation analysis is a BAU scenario for the GHG emissions from the base year until a "target" year. The forecast of energy consumption in the road transport, as the main determinant of the emissions, is done using the mathematical model described with Eqs. (1) and (2).

$$
\begin{aligned}
& Q_{g, i}=\sum_{v} Q_{v, g, i} \\
& Q_{v, g, i}=\frac{S_{i} * N_{i}}{10^{6}} * p_{g, i} * p_{v, i} * G_{g, v, i} * K_{g, v, i} * \rho,
\end{aligned}
$$

where: $v \in$ \{light-duty vehicle, goods vehicle, motorbike\}, $g \in$ \{gasoline, diesel, combination gasoline-LPG (Liquified Petroleum Gas)\}, $i$ - year, $Q_{g, i}$ - annual energy consumed from fuel of type $g$ in year $i, Q_{v, g, i}$ - energy consumed by vehicles of type $v$ that use fuel of type $g$ in year $i, S_{i}-$ level of motorization in year $i$ (number of vehicles per 1000 inhabitants), $N_{i}$ - number of inhabitants in year $i, p_{g, i}$ - share of vehicles that use fuel of type $g$ in year $i, p_{v, i}$ - share of vehicles of type $v$ in year $i, G_{g, v, i}-$ fuel efficiency of vehicle of type $v$, that uses fuel of type $g$ in year $i, K_{g, v, i}-$ annual average $\mathrm{km}$ for vehicle of type $v$, which uses fuel type $g$ in year $i, \rho-$ conversion factor, fuel tons in toe.

The GACMO model [20] is used to evaluate the economic and environmental effectiveness of potential mitigation measures. GACMO is based on the principle of calculating the reduction costs when individual reduction strategies replace high emission technologies under the same comparative basis (Eq. (3)). It aggregates and ranks the average cost of each emission reduction option, and then draws the reduction cost curve. GACMO can be used to rank the cost-effectiveness of various GHG reduction strategies in a transparent way, even when there is no detailed data available.

$\mathrm{CO}_{2}$ reduction cost $=\frac{S C_{m i t}-S C_{r e f}}{\mathrm{CO}_{2 r e f}-\mathrm{CO}_{2 m i t}}$,

where

$$
\begin{aligned}
& S C_{\text {mit }}=O \& M_{m i t}+F C_{m i t}+L I_{m i t} \\
& S C_{r e f}=O \& M_{r e f}+F C_{r e f}+L I_{r e f} \\
& L I_{m i t}=I_{m i t} * \frac{(1+r)^{l_{m i t} * r}}{(1+r)^{l_{m i t}}-1} \\
& L I_{r e f}=I_{r e f} * \frac{(1+r)^{l_{r e f} * r}}{(1+r)^{l_{e f}}-1} \\
& \mathrm{CO}_{2 \text { ref }}=F U_{r e f, g} * E Q_{g} \\
& \mathrm{CO}_{2 m i t}=F U_{m i t, g} * E Q_{g}
\end{aligned}
$$

$S C_{m i t}$ - annual total system cost of mitigation option, $S C_{r e f}-$ annual total system cost of reference option, $O \mathcal{E} M_{\text {ref }}$ - annual operation and maintenance cost of reference option, $O \mathcal{E} M_{m i t}-$ annual operation and maintenance cost of mitigation option, $F C_{m i t}-$ annual fuel cost of mitigation option, $F C_{\text {ref }}$ - annual fuel cost of reference option, $L I_{m i t}$ - levalized investment of mitigation option, $L I_{\text {ref }}-$ levalized investment of reference option, $I_{\text {ref }}$ - investment of reference option, $I_{m i t}-$ investment of mitigation option, $l_{\text {ref }}-$ lifetime of reference option, $l_{\text {mit }}$ - lifetime of mitigation option, $r-$ discount rate, $\mathrm{CO}_{2 m i t}$ - annual emissions of mitigation option, $\mathrm{CO}_{2 \text { ref }}$ - annual emissions of reference option, $E Q_{g}-$ emission coefficient of fuel of type $g, F U_{r e f, g}-$ fuel of type $g$ consumed in reference option, $F U_{m i t, g}$ - fuel of type $g$ consumed in mitigation option.

The mitigation scenario combines the emissions in the BAU scenario with the reductions in emissions introduced by the various mitigation options being evaluated. For each mitigation option, the technologies/practices that deliver energy/transport services in the BAU option are changed. A mitigation unit of emissions from these new technologies/practices offsets a unit of energy consumed in the BAU scenario. A very important assumption that is made in this regard is that the level of energy/transport 
service delivered by the BAU option and the mitigation option does not affect the demand for the energy/transport service. In other words, there is no change in the level of energy/transport service demand when the new technology/practice is introduced, e.g., the amount of person-km transported is the same. Here it can sometimes be difficult to draw the borderline between what is changed and what is unchanged. There can also be some welfare changes, e.g., usage of time, health benefits, which are difficult to quantify.

The structure of the mitigation options in the different sectors varies a lot. It is impossible to describe them all in the same standard format. Therefore, a flexible representation is used in GACMO for the selected mitigation options.

\section{Case study: Macedonian transport sector}

\subsection{Sector profile}

The profile of the national transport sector is compiled based on data provided in the National Energy Strategy [21] and the corresponding annual reports of the State Statistical Office [22].

The transport sector contributed with $10 \%$ in total GHG emissions for the period 1990-2002 and in 2009 contributed with 13\% [23]. It has had a considerable share in the national energy balance, $20.2 \%$ in 2006 and $25.3 \%$ in 2010. The energy consumption per capita in the transport sector amounts 200 toe per 1000 inhabitants, which is more than three times lower than the EU-27 average figure (650 toe per 1000 inhabitants). In the last five years there has been a slight increase, but still Macedonian figures considerably lag behind European ones.

Within the transport sector, the road transport has the highest share in the energy consumption (98\%). Gasoline and diesel have had a dominant role in the energy mix (Fig. 1). After 2000, there has been a drop in gasoline consumption on one hand, and on the other hand, an increase in diesel consumption. The LPG was introduced after 2000. Most vehicles run on gasoline, followed by diesel vehicles and mix gasoline-LPG vehicles (Fig. 2). Passenger cars dominate with $90 \%$ of all vehicles, the share of buses amounts to around $1 \%$, the share of the goods vehicles decreased from $6.4 \%$ in 2002 to $3.9 \%$ in 2010 , while the share of the special vehicles increased from $1.8 \%$ in 2002 to $4.2 \%$ in 2010 and the share of the rest is around $1 \%$. The number of passenger cars is increasing, although still modest compared to developed countries - 130 vehicles per 1000 inhabitants in 2006 and 170 in 2010.

Macedonia has had a very old car fleet. $55 \%$ of the passenger cars are older than fifteen years and $71 \%$ are older than thirteen years (Fig. 3). The same problem is with buses and goods vehicles. $62 \%$ of the buses, $74 \%$ of the goods vehicles and $27 \%$ of the special vehicles in 2010 are older than fifteen years.

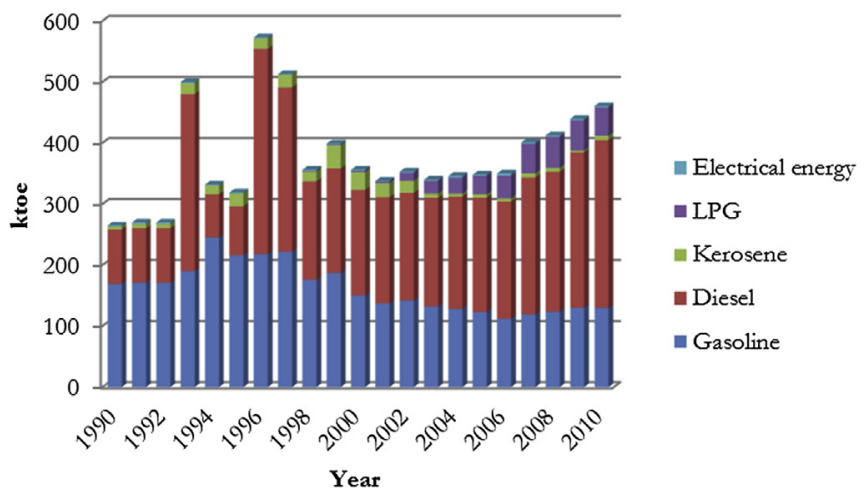

Fig. 1. Energy consumption in the transportation sector.

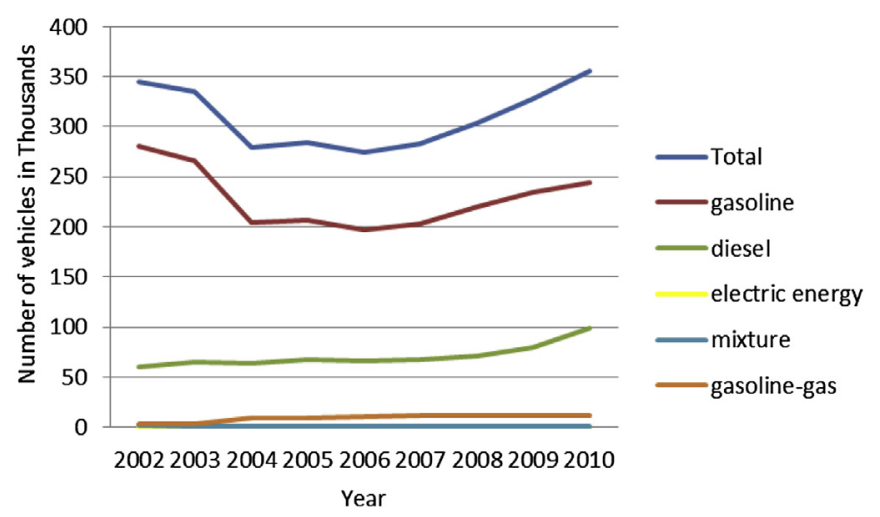

Fig. 2. Number of vehicles in road transport.

In general, the old fleet is slowly renewed. It is progressively enlarging, but the increment is mostly through used vehicles.

\subsection{Business-as-usual development pathway}

The annual increase of energy consumption in the transport sector over the period 2010-2020, estimated to 3.6\%, is higher than the annual increase of the total energy consumption in the country (3.1\%) [21], as well as much higher than the corresponding figure for developed countries (2\% [24]).

The motorization level in the country follows the " $S$ " curve. In the BAU scenario from the National Strategy for Energy Development from 2010 [21], a stable economic growth and return of the trend of motorization starting from 2010 is assumed, projecting the motorization level of 260 vehicles per 1000 inhabitants in 2020. Inline with the government policy which permits import of used vehicles in the last couple of years, as well as taking also into account the latest statistical data [22], the projections for the number of vehicles per 1000 inhabitants were shifted towards higher values at the beginning of the considered period, converging to the projections from the Strategy as the considered period ends.

The projections for the share of vehicles by fuel type were also revised. The latest statistical data show that the number of LPG vehicles is decreasing, so it is assumed that the share of LPG vehicles in 2020 will be the same as in 2010 . As for the diesel vehicles, the number in 2011 is higher than the projection in the Strategy, so the necessary adjustment was made. The share of gasoline vehicles follows the projection from the Strategy (Fig. 4).

Following the trends and statistical data beyond 2010, the Strategy projection of $1.4 \%$ annual rate of fuel efficiency improvement was also revised, assuming lower figure of $1.1 \%$. The corresponding

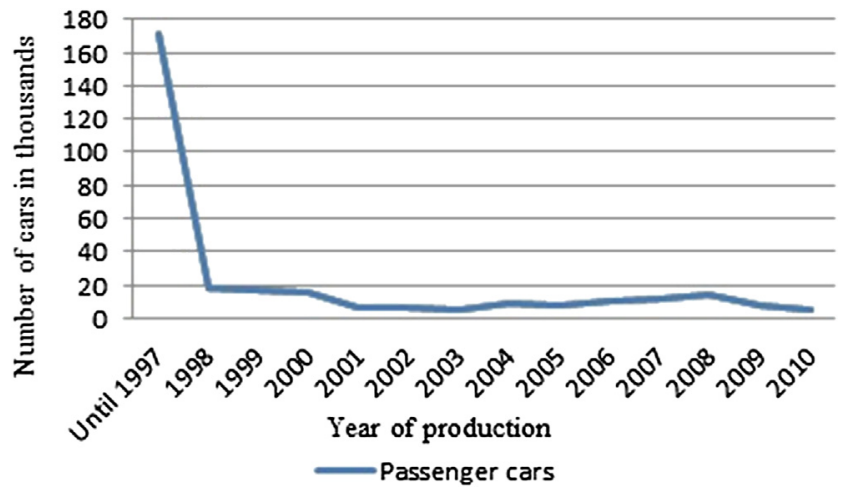

Fig. 3. Number of passenger cars by year of production. 


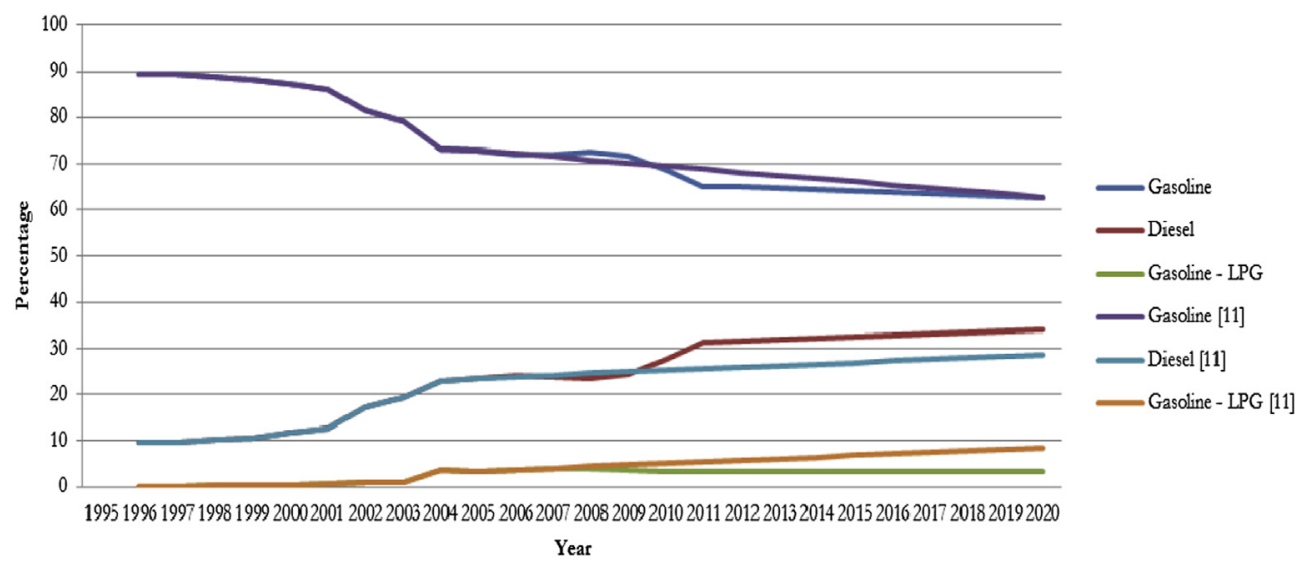

Fig. 4. Projected share of vehicles by fuel (adjusted projections vs. projections under BAU scenario of the Energy strategy [21]).

projections for fuel economy are given in Table 1. Accordingly, the consumption of diesel in 2020 will amount 427 ktoe, of gasoline 207 ktoe and of LPG 18 ktoe.

Taking into account these figures the BAU GHG emissions are calculated using the software package GHG protocol [25]. In 2020 , GHG emissions would amount $2 \mathrm{Mt} \mathrm{CO}_{2}$, which is almost double compared to the emissions from 1990 to 2010 (Fig. 5).

\subsection{Climate change mitigation options}

In this study, the potential reduction of GHG emissions of the national transport sector is analyzed through a combination of appropriate measures along the following mitigation strategies:

- improvement of vehicle fleet

- introduction of low carbon fuels

- improvement of travel behaviour

- advancement of vehicle equipment

- improvement of driver behaviour.

\subsubsection{Improvement of vehicle fleet}

In Macedonia, $72 \%$ of the vehicles were manufactured before the year 2000 and the number of vehicles is expected to increase significantly in the future. The main assumption of this mitigation strategy is that the owners of vehicles manufactured before 2000 will replace them by 2020 . This is inline with the finding that from an energy standpoint, an average vehicle in use in the EU does not justify its change until it is 20 years old [26]. Due to relatively low living standard and the governmental policy to allow import of used vehicles, there has been a practice of buying used vehicles. The considered vehicles categories under this mitigation strategy are as follows:

- old car - a car (gasoline, diesel or LPG) manufactured before 2008 with standard technology (Euro 1, Euro 2, Euro 3 and Euro 4 till 2008)

- new car - a brand new or used car (gasoline, diesel or LPG) manufactured after 2008 from middle class with advanced technology (Euro 4 (2008), Euro 5 and Euro 6)

Table 1

Fuel economy of the vehicles $[1 / 100 \mathrm{~km}]$.

\begin{tabular}{lllllll}
\hline $\begin{array}{l}\text { Year/ } \\
\text { Vehicles }\end{array}$ & $\begin{array}{l}\text { Gasoline } \\
\text { car }\end{array}$ & $\begin{array}{l}\text { Diesel } \\
\text { car }\end{array}$ & $\begin{array}{l}\text { Gasoline-LPG } \\
\text { car(gasoline } \\
\text { run) }\end{array}$ & $\begin{array}{l}\text { Gasoline-LPG } \\
\text { car(LPG run) }\end{array}$ & $\begin{array}{l}\text { Diesel } \\
\text { goods } \\
\text { vehicles }\end{array}$ & $\begin{array}{l}\text { Gasoline } \\
\text { motorbike }\end{array}$ \\
\hline 2010 & 8.3 & 7.5 & 8 & 10 & 35 & 4.7 \\
2020 & 7.4 & 6.7 & 7 & 8.9 & 27.4 & 3.8 \\
\hline
\end{tabular}

- used bus - 4-5-year-old bus, but with advanced technology (Euro 4)

- new bus - advanced technology (Euro 5 and Euro 6).

Data for all vehicle categories is shown in Table 2.

The annual fuel cost, annual operation and maintenance costs (registration, insurance, annual service and spares) and level of investment are given in Figs. 6 and 7.

A recent study [40] has shown that the impact of uncertainty on the fleet fuel use and GHG emissions is significant, and needs to be taken into account when analyzing the future of the vehicle fleet to inform more robust policy making, given the real world uncertainties in technology development and market behaviour.

In Macedonian conditions, the underlying issues of the assumptions for the vehicle fleet in the year 2020 are the following:

- the current purchasing trends, which are in favour of diesel cars due to their lower fuel consumption

- emerging market of LPG cars as a cheaper option, by technology but also by fuel

- the current trend in the country of replacement of old city buses with new buses (public transport company), as well as replacement of old city buses with newer used buses (private sector)

- the company buses (used for transport of employers) will be replaced by used buses or their engines will be replaced with better performance diesel engines. The replacement with new buses is not economically viable due to low number of kilometres the company buses pass.

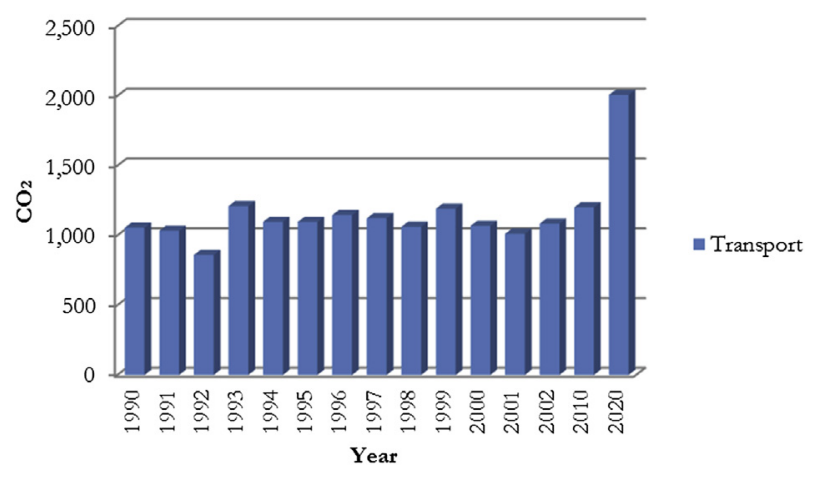

Fig. 5. $\mathrm{BAU} \mathrm{CO}_{2}$ emissions [kt]. 
Table 2

Input data for cars and buses.

\begin{tabular}{|c|c|c|c|c|c|c|}
\hline Vehicle category & & Average km & Average consumption $(\mathrm{l} / 100 \mathrm{~km})$ & Emissions $(\mathrm{g} / \mathrm{km})$ & Project life (year) & Investment (US\$) \\
\hline \multirow[t]{2}{*}{ Existing car } & Gasoline & 9000 & 10 & 228 & & \\
\hline & Diesel & 9000 & 8 & 214 & & \\
\hline \multirow[t]{2}{*}{ Old car } & Gasoline & 9000 & 8 & 183 & 5 & 4011 \\
\hline & Diesel & 9000 & 6.5 & 187 & 5 & 5348 \\
\hline \multirow[t]{4}{*}{ New car } & Gasoline & 9000 & 5.5 & 126 & 15 & 14,707 \\
\hline & Diesel & 9000 & 4.5 & 120 & 15 & 17,380 \\
\hline & LPG & 9000 & 7 & 112 & 15 & 13,370 \\
\hline & Hybrid & 9000 & 3.9 & 89 & 15 & 34,761 \\
\hline Existing city bus & Diesel & 41,072 & 39.3 & 1052 & & \\
\hline Used city bus & Diesel & 41,072 & 30 & 803 & 15 & 50,000 \\
\hline New city bus & Diesel & 41,072 & 25 & 669 & 20 & 170,000 \\
\hline Existing intercity bus & Diesel & 53,948 & 30 & 803 & & \\
\hline Used intercity bus & Diesel & 53,948 & 22 & 589 & 15 & 80,217 \\
\hline Existing intercity bus with new engine & Diesel & 53,948 & 25 & 669 & 10 & 17,000 \\
\hline Existing company bus & Diesel & 17,000 & 30 & 803 & & \\
\hline Existing company bus with new engine & Diesel & 17,000 & 25 & 669 & 10 & 17,000 \\
\hline
\end{tabular}

Car models: Toyota (model Yaris, Auris and Prius), Skoda (model Fabia), Fiat (model Punto and Linea) and Kia (model Ceed).

Bus models: taken from Refs. [35,36].

Emission factors for fuels: [37-39].

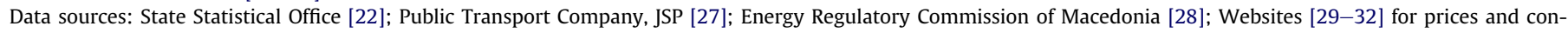
sumption of new vehicles; and Websites $[33,34]$ for prices and consumption of used cars.

\section{Assumptions for the year 2020:}

- 45,000 diesel cars will be replaced with new diesel cars.

- 60,000 gasoline cars will be replaced with new diesel cars.

- 70,000 gasoline cars will be replaced with new gasoline cars.

- 5000 gasoline cars will be replaced with hybrid cars.

- 20,000 gasoline cars will be replaced with new LPG cars.

- 15,000 diesel cars will be replaced with new LPG cars.

- 100 city buses will be replaced with new ones.

- 350 city buses will be replaced with used buses.

- 200 intercity buses will be replaced with used buses.

- 250 diesel engines of intercity buses will be replaced with better performance diesel engines.

- 300 diesel engines of company buses will be replaced with better performance diesel engines.

\subsubsection{Introduction of low carbon fuels}

In Macedonian conditions, the introduction of low carbon fuels is also considered among the key strategies for GHG emission reduction. In case of diesel fuel it is implemented with introduction of biodiesel, while in case of gasoline, the biofuel is ethanol. The fuel prices used as input data are shown in Table 3. As an EU candidate country, inline with the EU Renewables Directive (2009/ 28/EC), Macedonia should reach a $10 \%$ share of renewable energy

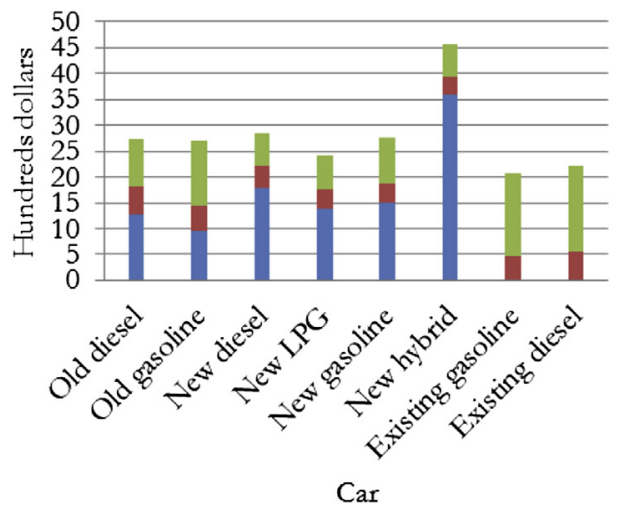

- Annual fuel cost

- Annual O\&M

Lev. of Invest. specifically in the transport sector by 2020 , which underlies the assumptions for this mitigation strategy.

\section{Assumptions for the year 2020:}

- Biodiesel will be introduced in the amount of $10 \%$ of total diesel consumption (42.7 ktoe).

- Ethanol will be introduced in the amount of $10 \%$ of total gasoline consumption (20.7 ktoe).

\subsubsection{Improvement of travel behaviour}

The considered measures under this mitigation strategy include use of public transport (instead of private cars) and walking or cycling instead of short distance driving.

In the first measure it is assumed that a person daily passes $10 \mathrm{~km}$ to and from office, which makes annually $2000 \mathrm{~km}$ (200 working days $\times 10 \mathrm{~km}$ ). The total annual costs if a private car is used would amount 544 US\$ (280 US\$ fuel costs and 264 US\$ parking costs). If a public bus is used the total annual costs is 217 US\$ (40 tickets for 10 drives $\times 5.4$ US\$) for bus tickets. The annual saving would be 327 US\$. If the car is shared by two persons, the annual saving would be 110 US\$, the travelled kilometres would amount 2000 (2 persons $\times 2000 \mathrm{~km} / 2$ car occupancy), against 134 travelled kilometres when public bus is used ( 2 persons $\times 2000 \mathrm{~km} / 30$ bus occupancy).

Fig. 6. Annul car costs.

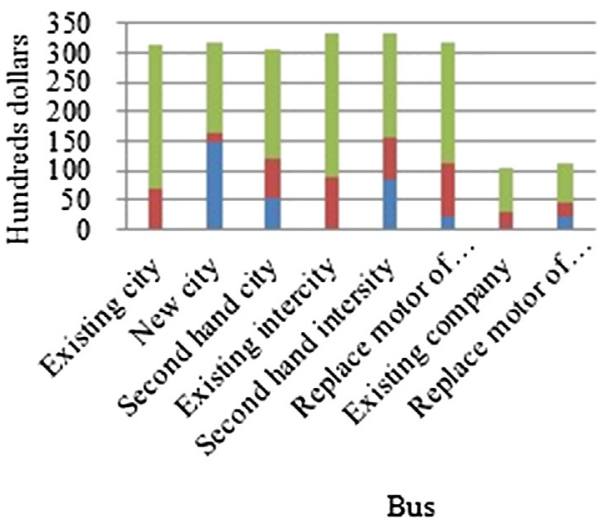

Fig. 7. Annual bus costs. annual fuel cost

- Annual O\&M

-Lev. of Invest. 
Table 3

Fuel prices.

\begin{tabular}{lll}
\hline Fuel & Price & Unit \\
\hline Diesel oil & 1.58 & US $\$ / 1$ \\
Gasoline & 1.77 & US $\$ 1$ \\
LPG & 1.02 & US $\$ / 1$ \\
Biodiesel & 1.60 & US $\$ / 1$ \\
Biogasoline & 1.81 & US $\$ / 1$ \\
\hline
\end{tabular}

In the second measure it is assumed that instead of car for short distance $(2 \mathrm{~km})$, the person would walk or use a bicycle. The annual saving is 72 US\$ (mainly fuel cost savings). This measure is more applicable in the small cities where people use their car for short distances. The assumed breakthrough rates of these measures in the year 2020 are based on the analyses of recent statistical data [22].

\section{Assumption for the year 2020:}

- The number of people using public transport will increase by 40,000 .

- The number of people walking or cycling instead of short distance driving will increase by 30,000 .

\subsubsection{Advancement of vehicle equipment}

The considered measures under this mitigation strategy include using low viscosity lubricant instead of conventional lubricant and using low rolling resistance tires instead of conventional tires.

Input data for these two measures are shown in Table 4. Michelin and Goodyear tires with low resistance and Shell low viscosity lubricant are considered. The advanced vehicle equipment would reduce the fuel consumption by $1.6 \%$ in case of low rolling resistance tires and by $4.6 \%$ in case of low viscosity lubricant.

The assumed breakthrough rates of these measures in the year 2020 are based on the analyses of the recent statistical and customs data and surveys of market for tires and lubricants.

\section{Assumption for the year 2020:}

- 300,000 cars will use low resistance tires.

- 300,000 cars will use low viscosity lubricant.

\subsubsection{Improvement of driver behaviour}

This strategy includes awareness raising campaigns aimed at improving the driver behaviour which considerably affects fuel economy. The campaigns should reach out to the drivers, making them aware about the following:

- Air conditioning in vehicles can increase fuel consumption by $8 \%$.

- Quick acceleration and heavy braking can reduce fuel economy by up to $33 \%$ on the highway and $5 \%$ around town.

- Idling consumes fuel, so it is better to turn off the engine if waiting for more than one minute. This can reduce the consumption by $3 \%$.

- Driving with $80 \mathrm{~km} / \mathrm{h}$ instead of $110 \mathrm{~km} / \mathrm{h}$ can reduce fuel consumption by $30 \%$.

Table 4

Input data for tires and lubricants.

\begin{tabular}{lc}
\hline Measure & Investment (US\$) \\
\hline Conventional lubricant & 12.2 \\
Low viscosity lubricant & 60.9 \\
Conventional tires & 438.3 \\
Low rolling resistance tires & 534.8 \\
\hline
\end{tabular}

- Driving on tires with air pressure at $50 \mathrm{kPa}\left(0.5 \mathrm{~kg} / \mathrm{cm}^{2}\right)$ below the recommended pressure decreases fuel efficiency by $2 \%$ and $4 \%$ in urban and suburban areas respectively.

On the bases of the costs for similar campaigns undertaken by the Government in recent years, it is assumed that 200,000 US\$ will be spent every year on awareness raising campaigns aimed at improvement of driver behaviour.

\section{Assumption for the year 2020:}

- The overall fuel consumption will be reduced by $1 \%$.

\section{Results}

\subsection{Marginal abatement cost curve}

The results obtained for specific costs and volume of reduction of $\mathrm{CO}_{2}$ emissions for each of the mitigation measures are presented in a form of MAC (Marginal Abatement Cost) curve (Fig. 8). The measures are introduced in the curve according to their costeffectiveness (the option with the smallest specific costs is introduced first on the left side of the curve).

Although environmental and economic effectiveness for each of the measures were calculated separately, in order to facilitate the prioritization of the mitigation efforts the results are presented at the level of mitigation strategy. Hence, in Table 5, the results including specific costs and volume of reduction of $\mathrm{CO}_{2}$ emissions and the assumed penetration rate of the technology/practice in 2020 for each mitigation strategy (4.1-4.5) are presented. The corresponding MAC curve is shown in Fig. 9.

The reduction cost in 2020 varies in the range from -625 to 98 $\mathrm{US} \$ / \mathrm{tCO}_{2}$. The total achievable reduction (if all considered options are implemented with the assumed breakthrough rate) in 2020 is estimated to be $0.45 \mathrm{MtCO}_{2}$, or $22 \%$ of the $2020 \mathrm{BAU}$ emissions $\left(2 \mathrm{MtCO}_{2}\right)$. "Introduction of low carbon fuels" has the greatest contribution to $\mathrm{CO}_{2}$ emission reduction with annual reduction of $0.26 \mathrm{MtCO}_{2}$, followed by "improvement of vehicle fleet" with annual reduction of $0.12 \mathrm{Mt} \mathrm{CO}_{2}$.

The most cost effective mitigation strategy appears to be "improvement of driver behaviour", followed by "improvement of travel behaviour" and "advancement of vehicle equipment". These three strategies are of win-win type (with negative specific costs). On the other hand, mitigation strategies with relatively high marginal costs are "introduction of low carbon fuels" and "improvement of vehicles fleet".

\subsection{Sensitivity analyses}

A study on the marginal abatement costs in the UK transport sector [41] has shown that earlier efforts and expectations about future carbon policies have a noticeable influence on abatement costs and in general, on the shape and structure of a static MAC curve.

In Macedonian conditions, the most pronounced influence could be related to the LPG taxation policy, as well as to the level of market penetration of CNG (Compressed Natural Gas). The current LPG tax in Macedonia is $80 €$ per $1000 \mathrm{~kg}$ [42], while the taxes for other fuels are the same as in the EU. According to the recently proposed EU legislation, the LPG tax will increase from current $125 €$ per $1000 \mathrm{~kg}$ to $500 €$ per $1000 \mathrm{~kg}$ [43]. The calculations conducted with the highest EU tax have shown significant decrease in the economic effectiveness of the mitigation strategy "improvement of vehicles fleet", since the corresponding figure rises from 98 to $164 \mathrm{US} \$ / \mathrm{tCO}_{2}$.

Other source of uncertainty is the extent to which the CNG will be used to support the decarbonization in the case of gasoline. 


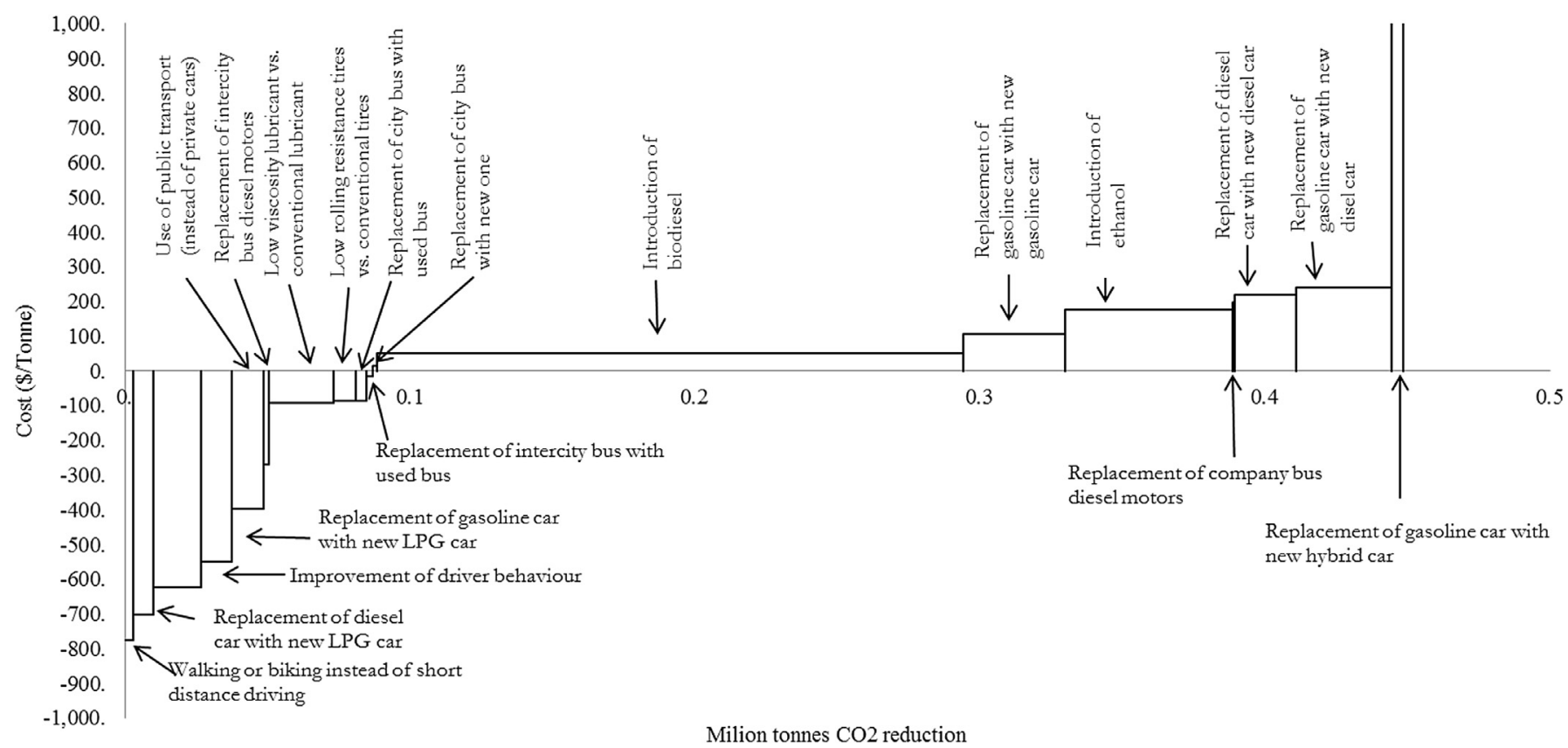

Fig. 8. Marginal cost curve of the transport mitigation measures for the year 2020

The utilization of CNG considerably varies among EU countries. Italy and Bulgaria have the highest CNG share in road transport fuel consumption of around 2.5\%. During the period from 2000 to 2010 the number of CNG vehicles in Italy increased from 320,000 to 730,000 vehicles, while in Spain from 912 to 2539 vehicles [44].

At the moment, in Macedonia there are only three CNG stations - one located on the Corridor 10, near Kumanovo (MAKPETROL "mother" station), other in Skopje (settlement Vlae) (MAKPETROL "daughter" station), and the third one belongs to the Public Transport Enterprise JSP. The current price of CNG is $1.35 \mathrm{US} \$ / \mathrm{kg}$ and the cost of installation of CNG system ranges from 1800 to 2070 US\$, which makes CNG option very attractive from economic point of view. Although the fuel is relatively cheap, the main problem hindering the higher utilization of CNG is the territorial coverage with CNG stations. The development of the CNG infrastructure is strongly related to the availability of natural gas, so in the situation when the network for natural gas transmission and distribution is undeveloped, the penetration of CNG is uncertain and difficult to predict. Therefore, for the time being, we just emphasize the potential of CNG for achieving GHG emission reduction at low price, which can be harnessed once the availability of natural gas is ensured.

If Macedonia follows the Bulgarian or Italian example, the number of CNG vehicles in 2020 will reach 20,000 , which implies that $5 \%$ of ethanol will be replaced with CNG. Since introduction of
CNG is a win-win measure, it will considerably improve the economic effectiveness of the strategy "introduction of low carbon fuels", reducing the specific costs from 91 to $72 \mathrm{US} \$ / \mathrm{t} \mathrm{CO}_{2}$. The total achievable emission reduction will decrease from $22 \%$ to $21 \%$ because of the higher $\mathrm{CNG}$ emission factor.

\section{Discussion}

\subsection{Prioritization of the mitigation strategies}

The analytical work delivered two parameters for each mitigation strategy - environmental effectiveness and economic effectiveness, which serve well in addressing the environmental and economic aspects of the mitigation efforts. Although highly important, these two dimensions are not sufficient for comprehensive evaluation, which, as recommended in Ref. [45], is the key to identifying truly optimal solutions to transport problems. Indeed, to better inform policy and strategic action it is critical to explore and evaluate the feasibility of the mitigation strategy, since there might be cases when mitigation efforts with high economic and/or environmental performance cannot be realized due to country-specific barriers, be they financial, institutional, legislative, administrative or technical ones (infrastructures and supply chain gaps, involvement of many stakeholders with different interests, as well as, lack of relevant data, studies and knowledge in general).

Table 5

Summary of the economic and environmental evaluation of the mitigation strategies in the transport sector

\begin{tabular}{|c|c|c|c|c|c|c|c|}
\hline \multirow[t]{3}{*}{ Reduction option } & \multirow[t]{3}{*}{$\mathrm{US} \$ / \mathrm{CO}_{2}$} & \multirow[t]{3}{*}{ Unit type } & \multirow{3}{*}{$\begin{array}{l}\text { Emission reduction } \\
\mathrm{t} \mathrm{CO}_{2} \text { /unit }\end{array}$} & \multirow{3}{*}{$\begin{array}{l}\text { Units penetrating } \\
\text { in } 2020\end{array}$} & \multicolumn{3}{|c|}{ Emission reduction in 2020} \\
\hline & & & & & \multirow{2}{*}{$\frac{\text { Per option }}{\text { Mt/year }}$} & \multicolumn{2}{|l|}{ Added } \\
\hline & & & & & & Mt/year & Fraction of total (\%) \\
\hline Improvement of driver behaviour & -625 & Campaign & 16,762 & & 0.02 & 0.02 & 0.01 \\
\hline Improvement of travel behaviour & -560 & Passenger & 0.20 & 70,000 & 0.01 & 0.03 & 0.02 \\
\hline Advancement of vehicle equipment & -91 & $\begin{array}{l}4 \text { tires } \\
41 \text { lubricant }\end{array}$ & 0.05 & 600,000 & 0.03 & 0.06 & 0.03 \\
\hline Introduction of low carbon fuels & 91 & $26.5 \mathrm{PJ}$ & 264,053 & 1 & 0.26 & 0.33 & 0.16 \\
\hline Improvement of vehicle fleet & 98 & Vehicle & 0.57 & 216,200 & 0.12 & 0.45 & 0.22 \\
\hline
\end{tabular}




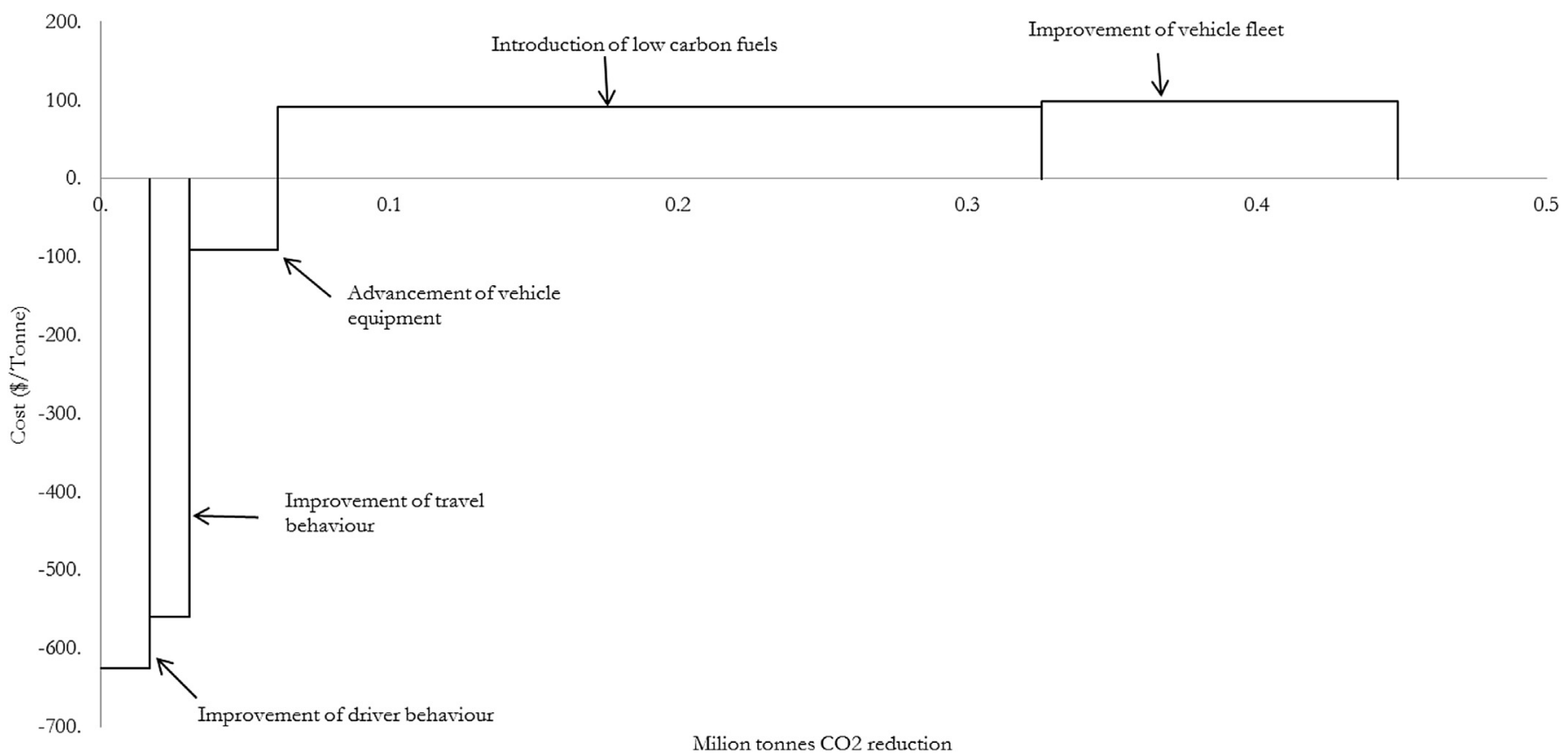

Fig. 9. Marginal cost curve of the transport mitigation strategies for the year 2020.

Furthermore, in light of the MRV as an essential element of NAMAs (Nationally Appropriate Mitigation Actions), measurability of the achieved emissions reductions should act as a partial determinant of the policy decisions that are guided and bolstered by the mitigation achievements (including policy decisions for appropriate country-specific emission reduction/limitation targets). Moreover, associating measurement methodologies to the mitigation action will open possibilities for linking the national mitigation actions to international support (which is among the topics of the international negotiations about the future of the climate regime).

Finally, it is becoming clear that co-benefits can help to make the economic case for climate change mitigation measures. Hence, the majority of the co-benefits associated with climate change mitigation strategies for the transport are directly related to human health, including:

- improved air quality due to reduced emissions of air pollutants from transport

- increase in the amount of physical exercise carried out by the population in general due to a shift to non-motorised transport modes (cycling and walking)

- reductions in the number and/or severity of traffic accidents

- reduced ambient noise levels due to quieter low carbon vehicles

- indirect effects related to the life cycle effects of vehicles, energy carriers or infrastructure.

Other co-benefits associated with climate change mitigation strategies, particularly with the reinforcement of low carbon fuels, include diversification of income in rural areas and creation of new jobs.

In the next phase, a thematic workshop was organized aimed at prioritization of the mitigation strategies applying a participatory approach. The workshop created an environment of dialogue and cooperation among a range of transport stakeholders in the articulation of their views and perspectives about the priorities of the national transport policy, accountable also for climate change mitigation. Firstly, the participants of the workshop were asked to present their opinion about the importance of the following criteria, which are to be applied in the subsequent phase of the mitigation strategies evaluation:

- economic effectiveness (price of reduction)

- environmental effectiveness (volume of reduction)

- feasibility (difficulty of implementation)

- measurability (difficulty of measuring and verification of the achieved emissions reductions)

- co-benefits (health benefits, diversification of income, new jobs, life quality).

The results of the criteria weighing exercise, according to the workshop participants, show that all the criteria are almost equally important (with relatively close weight). Still, the participants assigned "feasibility" as the strongest determinant of the "quality" of the mitigation strategy, followed by the economic effectiveness and environmental effectiveness.

Once the criteria and their weights were set, the participants were asked to evaluate each of the five mitigation strategies with marks 1 (lowest) to 5 (highest) against each criterion. The analytical phase of this assignment provided quantified values for the first two criteria (environmental effectiveness and economic effectiveness), so the evaluation according to these two criteria was straightforward. With regards to the remaining three criteria the participants performed the evaluation on the basis of their personal understanding and knowledge.

Owing to its highest environmental effectiveness, considerable health and socio-economic co-benefits and relatively good measurability and feasibility, the introduction of low carbon fuels is the wining mitigation strategy in the transport sector. This is also inline with the EU target for the share of biofuels in total energy consumption of the transport sector.

Definitely, the lowest specific cost (or highest economic effectiveness) accompanied with easiness of implementation was the decisive factor for the second score of the improvement of driver behaviour. However, the achieved emission reduction is difficult, if 
not impossible, to measure. For the same reasons plus the associated health co-benefits, the improvement of travel behaviour took the third place in the ranking list. Quantification and measurement is a pressing problem relevant for this mitigation strategy also.

Although with relatively high environmental effectiveness and specific costs similar to the ones of the introduction of low carbon fuels, the improvement of vehicle fleet took the lower part of the ranking list. The possible reasons should be looked at the decisionmaking at car-owner level, thus making harmonized action difficult to implement, as well as at the fact that the investment comes from the family budget, which directly affects the decision about purchasing a new vehicle. The measurability of the achieved emissions reductions could be an issue since detailed and disaggregated data are needed about the vehicles, fuel consumption, and kilometres passed.

Finally, the last on the ranking list is the mitigation strategy related to advancement of vehicle equipment. This can be explained with the moderate or low scores of this strategy against all criteria. Again, the measurability of the achieved reductions is a pressing problem, since it is difficult to record the individual actions along this mitigation strategy.

\subsection{Policy recommendations}

Achieving reductions in road transport GHG emissions will require a broad policy response. The national road transport mitigation strategies prioritized by transport sector stakeholders taking into account their economic effectiveness, environmental effectiveness, feasibility, measurability and co-benefits include:

- priority 1: Introduction of low carbon fuels

- priority 2: Improvement of driver behaviour

- priority 3: Improvement of travel behaviour

- priority 4: Improvement of vehicle fleet

- priority 5: Advancement of vehicle equipment.

\subsubsection{Introduction of low carbon fuels}

According to Ref. [46] it is necessary for the Government to adopt a Rulebook on the manner of securing relevant share of biofuels in the total energy consumption in transport. It is recommended to do this by putting the blends into market circulation under clearly defined dynamics aimed to increase share of biofuels, initially with diesel fuels, and later with petrol fuels as well. For that purpose, measures are needed by which the State will promote the use of blends with biofuels without significant increase of fuel prices (by reducing the excise on biofuels and by introducing increased excise for oil derivatives not used in transport). In addition, as part of the program on agricultural development, it is necessary to stimulate the production of domestic raw materials for biofuels by supporting producers of biofuels to invest in agricultural production of raw materials, guaranteed purchase, favourable crediting lines, etc.

The CNG has a considerable potential for reduction of GHG emissions at low (even negative) costs. However, the higher utilization is conditioned by gasification of the country. Some examples of CNG support include: Italy - grants of up to $2000 €$ to purchase new CNG vehicle and grants of up to $650 €$ for converting a vehicle (until 2009) [44]; Spain - grants of up to $2000 €$ for new buses or refuse trucks, lower tax on natural gas as vehicle fuel (approx. 6.5 times lower than diesel), and grants of up to $60,000 €$ for filling stations.

\subsubsection{Improvement of driver behaviour}

Minimizing unnecessary braking (for instance, by not tailgating), observing the speed limit, anticipating the actions of other drivers, and avoiding excessively rapid acceleration can increase kilometres per litter by a few percent over normal driving behaviour. Studies of programs to promote these behaviours, however, have found that it is difficult to sustain the gains without regular awareness raising campaigns and driver training.

\subsubsection{Improvement of travel behaviour}

This strategy includes more actions aimed at promotion of more sustainable modes of transport and travel behaviour. The implementation of some of these measures requires big investments and must be part of greater national projects. In this study we considered using public transport instead of a car and cycling and walking instead of driving. This will be facilitated by:

- Renewal of public transport bus fleet in order to increase the use of public transport.

- Promotion of greater use of bicycle. This measure includes investments in the bicycle network infrastructure, as well as a public campaign for greater bicycle use.

Furthermore, this mitigation strategy should also include the following measures, which are considered in Ref. [47] as well:

- Introduction of tramway in Skopje. The benefits of new public transport fleet for the city of Skopje and its citizens are numerous and valuable. The greater energy efficiency and the lower pollution of the environment are just a small part of the total benefits, the detailed analysis of which is out of scope of this report.

- Introduction of integrated traffic management centre, in particular within the centre city of Skopje (the small and the big ring).

- Parking policy. The aim of this measure is to discourage the use of automobiles in the cities. Therefore, the implementation of this measure (paid parking) should result in positive financial effects for both: the cities (increased local budget) and for the government (reduced fuel consumption). The city of Skopje has already introduced the concept of zone parking in the centre city. It is implemented by the local public company for parking.

- Car-free days. The implementation of this measure includes the public campaign through media (TV, radio, posters, etc.).

- Promotion of greater use of railway for intercity travel. The improvement of the railway infrastructure in Macedonia is a capital undertaking that includes huge investments. However it is expected, within this measure, to increase the railway intercity passenger ridership by improvement of rail timetables - better service suited to the passenger needs, and by public campaign.

\subsubsection{Improvement of vehicle fleet}

As recommended in Ref. [47], the promotion and support of this measure should be achieved through regulatory and fiscal measures implemented by the government. The possible policy measures can be aimed at achieving incentives for purchasing and using clean and energy efficient cars. Hence, the first group of policy measures may include various schemes, such as:

- Reduction of taxes for the purchase of new clean and energy efficient cars and keeping the same existing costs for other cars.

- Reduction of taxes for the purchase of new clean and energy efficient vehicles and increasing the taxes for other cars.

- Provision of bank credits with lower interest rates, if a new clean and energy efficient car is purchased. The difference 
from commercial rates can be covered by the government, but also other financial arrangements can be made between the government and the commercial banks.

The second group of policy measures includes schemes such as:

- Lower costs for vehicle registration for clean and energy efficient cars

- Lower costs for parking in the centre of the city for clean and energy efficient cars

- Lower ecological tax and tax on property (if there is any) for clean and energy efficient cars.

\subsubsection{Advancement of vehicle equipment}

This strategy is aimed at promoting the utilization of advanced equipment (i.e. low resistance tires and low viscosity lubricant) which can considerably contribute to fuel economy improvement. Furthermore, it is possible to reduce the fuel consumption by another few percent via optimal vehicle maintenance. Here again, regular awareness raising campaigns and driver training are crucial factors of success.

\section{Conclusion}

The analytical framework for assessment of climate change mitigation potential for transport sector in developing countries is adapted in order to incorporate the expected increase in vehicle fleet with used vehicles, and then used on the case of Macedonian transport sector. The main findings of study can be summarized as follows:

- The total achievable reduction in the transport sector (if all considered mitigation strategies are implemented with the assumed breakthrough rate) in 2020 is estimated to be $0.45 \mathrm{Mt} \mathrm{CO}_{2}$, or $22 \%$ of the BAU emissions.

- Three of the five mitigation strategies are of negative costs (win-win type) although with relatively low environmental effectiveness: $4 \%$ of the achievable reduction can be realized at negative costs. These strategies include improvement of driver behaviour, improvement of travel behaviour and advancement of vehicle equipment.

- The bulk of the achievable emission reduction can be realized at relatively high specific costs (around $90 \mathrm{US} \$ / \mathrm{t} \mathrm{CO}_{2}$ ).

- The highest environmental effectiveness is associated with the introduction of low-carbon fuels $\left(0.25 \mathrm{Mt} \mathrm{CO}_{2}\right)$, which is more than half of the total achievable emission reduction.

- The highest economic effectiveness is associated with the raising awareness campaigns aimed at improvement of driver behaviour ( $\left.-625 \mathrm{US} \$ / \mathrm{tCO}_{2}\right)$.

These figures are indicative and depend strongly on the assumptions. Therefore, it is very important to revisit the assumptions at regular intervals and incorporate into this framework the new learning and data obtained with time.

Achieving reductions in road transport GHG emissions will require a broad policy response, as comprehensively elaborated in Section 5.2.

Similarly to recommendations for further research from Refs. [48,49], in Macedonian conditions, the follow-up modelling should be focused on the relationship between transport, energy, land use, and emissions. In addition, flexible integrated assessment tools should be applied in order to assess a range of scenarios and evaluate the effect of different policies, including those for climate change mitigation.

\section{Acknowledgement}

The presented analysis is a part of the project "Third National Communication to the UNFCCC: Case study of climate change mitigation potential of the transport sector" financed by UNDP. The authors gratefully acknowledge the support from UNDP and Ministry of Environment and Physical Planning, as well as the contribution of the key stakeholders through interviews and participation in the thematic workshop.

\section{References}

[1] Intergovernmental Panel on Climate Change (IPCC). Climate change 2007: syntheses report. Contribution of working groups I, II and III to the fourth assessment report of the Intergovernmental Panel on Climate Change. Geneva 2007.

[2] Duic N, Juretic F, Zeljko M, Bogdan Z. Croatia energy planning and Kyoto Protocol. Energy Policy 2005;33(8):1003-10.

[3] Huang MW, Lee WMG. Feasibility analysis of GHG reduction target: lesson from Taiwan's energy policy. Renewable and Sustainable Energy Reviews 2009;13(9):2621-8.

[4] Matsuoka Y, Fujino J, Kainuma M. National implications of a 50\% global reduction of greenhouse gases, and its feasibility in Japan. Sustainability Science 2008;3(1):135-43.

[5] Delarue E, Lamberts H, D'haeseleer W. Simulating greenhouse gas (GHG) allowance cost and GHG emission reduction in Western Europe. Energy 2007;32(8):1299-309.

[6] Dedinec A, Markovska N, Taseska V, Kanevce G, Bosevski T, Pop-Jordanov J The potential of RES for GHG emissions reduction. Thermal Science 2012;16(3):717-28

[7] Taseska V, Markovska N, Causevski A, Bosevski T, Pop-Jordanov J. GHG emissions reduction in a power system predominantly based on lignite. Energy 2011;36(4):2266-70.

[8] Ćosić B, Markovska N, Taseska V, Krajačić G, Duić N. The potential of GHC emissions reduction in Macedonia by renewable electricity. Chemical Engineering Transactions 2011;25:57-62.

[9] Yang C, McCallum D, McCarthy R, Leighty W. Meeting an $80 \%$ reduction in greenhouse gas emissions from transportation by 2050: a case study in California. Transportation Research Part D: Transport and Environment 2009;14(3):147-56

[10] Kromer M, Bandvivadekar A, Evans C. Long-term greenhouse gas emission and petroleum reduction goals: evolutionary pathways for the light-duty vehicle sector. Energy 2010;35(1):387-97.

[11] Stanley JK, Hensher DA, Loader C. Road transport and climate change: stepping off the greenhouse gas. Transportation Research Part A 2012;46:517-48.

[12] Nogueira LAH. Does biodiesel make sense? Energy 2011;36:3659-66.

[13] Gul T, Kypreos S, Turton H, Barreto L. An energy-economic scenario analysis of alternative fuels for personal transport using the Global Multi-regional MARKAL model (GMM). Energy 2009;34:1423-37.

14] Guerrero-Lemus R, Marrero GA, Puch LA Costs for conventional and renewable fuels and electricity in the worldwide transport sector: a mean-variance portfolio approach. Energy 2012;44:178-88.

[15] Timilsina GR, Shrestha A. How much hope should we have for biofuels? Energy 2011;36:2055-69.

[16] Manzini F. Inserting renewable fuels and technologies for transport in Mexico City Metropolitan Area. International Journal of Hydrogen Energy 2006;31(3): 327-35.

[17] Hao H, Wang H, Ouyang M. Fuel conservation and GHG (greenhouse gas) emissions mitigation scenarios for China's passenger vehicle fleet. Energy 2011;36(11):6520-8

[18] Du JD, Han WJ, Peng YH, Gu CC. Potential for reducing GHG emissions and energy consumption from implementing the aluminium intensive vehicle fleet in China. Energy 2010;35(12):4671-8.

[19] González Palencia J, Furubayashi T, Nakata T. Energy use and $\mathrm{CO}_{2}$ emissions reduction potential in passenger car fleet using zero emission vehicles and lightweight materials. Energy 2012;48:548-65.

[20] Callaway MJ, Fenham J, Gorham R, Makundi W, Sathaye J. Economics of greenhouse gas limitations. Handbook reports sectoral assessments. Denmark: UNEP Collaboration Centre on Energy and Environment, Riso National Laboratory; 1999.

[21] Ministry of Economy of the Republic of Macedonia. Strategy for energy development in the Republic of Macedonia until 2030. Skopje 2010.

[22] State Statistical Office of the Republic of Macedonia. Transport and other services, 2007, 2008, 2009, 2010, 2011. Skopje 2012.

[23] Ministry of Environment and Physical Planning of the Republic of Macedonia. Second national communication on climate change under UNFCCC. UNDP/ GEF; 2008.

[24] Warren J. Managing transport energy: power for a sustainable future. Oxford University Press; 2007.

[25] GHG emissions from transport or mobile sources software, version 2.3. URL: http://www.ghgprotocol.org/calculation-tools/all-tools [last accessed 22.02.13]. 
[26] Usón AA, Capilla AV, Bribián IZ, Scarpellini S, Sastresa EL. Energy efficiency in transport and mobility from an eco-efficiency viewpoint. Energy 2011;36: 1916-23.

[27] Public Transport Company. JSP. Annual report for 2010. Skopje April 2011.

[28] Energy Regulatory Commission of Macedonia. Decision on determination of the highest price of oil derivates [Одлука за оШределување на највисока цена на одделни нафтени деривати соГласно МетодолоГијата]. Skopje 19.12.2011 [in Macedonian].

[29] URL: http://www.toyota.com.mk/ [last accessed 16.01.13].

[30] URL: http://www.skoda.com.mk/ [last accessed 16.01.13].

[31] URL: http://fiat.com.mk/ [last accessed 16.01.13].

[32] URL: http://www.kiamotors.com.mk/ [last accessed 16.01.13].

[33] URL: http://www.pazar3.mk/mk/Listing\#id_location=0\&id_category= $3016 \& q=\& a d_{-}$-type $=$ForSale [last accessed 16.01.13].

[34] Natural Resources Canada. Fuel consumption guide 20112011.

[35] URL: http://www.yutong.com/english/products/index.jsp?cid=2768abe96c83-4b77-8ddb-a0b9e2c6712e [last accessed 16.01.13].

[36] URL: http://www.laz.ua/en/prod/ [last accessed 16.01.13].

[37] 2006 IPCC guidelines for national greenhouse gas inventories. URL: http:// www.ipcc-nggip.iges.or.jp/public/2006gl/index.html [last accessed 22.02.13]

[38] Table 2, Carbon dioxide emission factors for transportation fuels. URL: http:// 205.254.135.7/oiaf/1605/coefficients.html [last accessed 22.02.13].

[39] Herold A. Comparison of $\mathrm{CO}_{2}$ emission factors for fuels used in Greenhouse Gas Inventories and consequences for monitoring and reporting under the EC emissions trading Scheme. ETC/ACC technical paper 2003/10. European Topic Centre on Air and Climate Change; July 2003.
[40] Bastani P, Heywood JB, Hope C. The effect of uncertainty on US transportrelated GHG emissions and fuel consumption out to 2050. Transportation Research Part A 2012;46:517-48.

[41] Kesicki F. Intertemporal issues and marginal abatement costs in the UK transport sector. Transportation Research Part D 2012;17:418-26.

[42] URL: http://www.ujp.gov.mk/files/attachment/0000/0017/Zakon_za_akcizite_ 34_2010_111.03.2010.pdf [last accessed 22.02.13].

[43] URL: http://ec.europa.eu/taxation_customs/taxation/excise_duties/energy_ products/legislation/index en.htm [last accessed 22.02.13]. Document URL: http://ec.europa.eu/taxation_customs/resources/documents/taxation/ minima_explained_en.pdf [last accessed 22.02.13].

[44] Callanan P., Foley A. Natural gas as a transportation fuel. Proceeding of the ITRN 2011, University College Cork, 31 August-1 September.

[45] Litman T. Comprehensive evaluation of energy conservation and emission reduction policies. Transportation Research Part A 2013;47: 153-66.

[46] Ministry of Economy of the Republic of Macedonia. National strategy for utilisation of renewable energy sources by 2020. Skopje 2010.

[47] Ministry of Economy of the Republic of Macedonia. Energy efficiency strategy of the Republic of Macedonia. Skopje 2010.

[48] Huzayyin AS, Salem H. Analysis of thirty years evolution of urban growth, transport demand and supply, energy consumption, greenhouse and pollutants emissions in Greater Cairo. Research in Transportation Economics 2013;40:104-15.

[49] Turton H. ECLIPSE: an integrated energy-economy model for climate policy and scenario analysis. Energy 2008;33:1754-69. 